Article

\title{
Fertigation of Maize with Digestate Using Drip Irrigation and Pivot Systems
}

\author{
Viviana Guido ${ }^{1, *}$, Alberto Finzi ${ }^{1}\left(\mathbb{D}\right.$, Omar Ferrari ${ }^{1}$, Elisabetta Riva ${ }^{1}$, Dolores Quílez ${ }^{2}{ }^{\circledR}$, \\ Eva Herrero ${ }^{2}$ and Giorgio Provolo ${ }^{1}$ (D) \\ 1 Department of Agricultural and Environmental Sciences, University of Milan, Via Celoria 2, \\ 20133 Milano, Italy; alberto.finzi@unimi.it (A.F.); omar.ferrari@unimi.it (O.F.); elisabetta.riva@unimi.it (E.R.); \\ giorgio.provolo@unimi.it (G.P.) \\ 2 Department of Soil and Irrigation, Agrifood Research and Technology Centre of Aragon (CITA), Avda. \\ Montañana 930, 50059 Zaragoza, Spain; dquilez@aragon.es (D.Q.); eherrero@cita-aragon.es (E.H.) \\ * Correspondence: viviana.guido@unimi.it
}

Received: 22 August 2020; Accepted: 21 September 2020; Published: 23 September 2020

\begin{abstract}
Digestate is a nutrient-rich fertilizer and appropriate techniques are required for its application during the maize season to reduce losses and increase the nitrogen use efficiency (NUE). The performance of two different fertigation techniques (drip irrigation and pivot) were assessed using the digestate liquid fraction. A two-year field test was carried out at two different sites in Lombardy, northern Italy. At each site, fertigation with pivot (P-F, site 1) or drip (D-F, site 2) systems was compared to reference fields where the same irrigation techniques without addition of digestate were used. During the two seasons, the performance of the fertigation systems, amount of fertilizers used, soil nitrogen content, yields, and nitrogen content of the harvested plants were monitored. The digestate application averaged $5 \mathrm{~m}^{3} /$ ha per fertigation event with P-F and $4.9 \mathrm{~m}^{3} / \mathrm{ha}$ with D-F corresponding, respectively, to 28 and $23 \mathrm{~kg} \mathrm{~N} / \mathrm{ha}$. Both irrigation systems were suitable for fertigation provided that the digestate was adequately filtrated. Our results suggest that fertigation with digestate, if properly managed, can be applied during the growing season up to the full amount of nitrogen required by the crop.
\end{abstract}

Keywords: slurry management; digestate liquid fraction; sustainability; nitrogen-use-efficiency; nitrogen balance; emission reduction; side-dressing fertilization

\section{Introduction}

Recovery of nutrients that come from waste streams has become essential in the evolution of a bio-based economy. Costs of energy and fertilizers are increasing, and fossil energy is necessary to produce mineral fertilizers. Biogas production through anaerobic digestion can address the increasing desire for green technology. Besides biogas, the result of this process is a nutrient-rich digestate that can be used as fertilizer in agriculture [1]. Thus, digestate and its fractions (solid and liquid) can replace mineral fertilizers with subsequent reduction in energy use and greenhouse gas emissions for their production [2]. Therefore, a dual environmental and economic benefit can be achieved by replacing resource-demanding mineral fertilizers with recycled nutrients in the agricultural production system while progressing towards a circular economy.

Manure application on fields is considered to be the best solution for supplying nutrients to crops and closing the nutrient cycle [3,4]. Nitrogen is present in manure and slurry in both mineral and organic forms. The mineral forms, mainly ammonium-N, are rapidly available to plants, which allows for a direct replacement of mineral fertilizers during the year of application [5-7]. Organic-N becomes 
available after its mineralization in the soil (months or years after application); this residual effect should be considered when planning fertilization [8].

In general, the nutrient composition of digestate is determined by the nature of the feedstock used in the biogas plant and the kind of digestion process adopted $[9,10]$. Consequently, numerous studies were conducted to analyze the potential uses and risks of adopting digestate as fertilizer, which were principally linked to the environmental problems of ammonia emission [11-13] and water pollution [14], the effect of introducing solid-liquid separation techniques [15], and the removal of excess phosphorous and heavy metals [16]. Furthermore, the specific biogas installation, geographical area, type of feedstock and digestate, and application techniques are topics requiring consideration [17].

According to best practices [18], the liquid fraction of digestate should be applied using precision application equipment, such as band spreaders, and then incorporated rapidly into the soil, or shallow/deep injectors $[2,19,20]$, to minimize emissions of ammonia into the atmosphere [21].

Another application technique for the liquid fraction of digestate promoted by United Nations Economic Commission for Europe [7] is fertigation. This technique is a practice in which fertilizer is applied using irrigation water. Although fertigation techniques can be applied using any irrigation systems, pressurized irrigation systems are preferred to flooding irrigation systems [22] as these systems provide a more uniform application of water and fertilizer as well as higher water use efficiency, which is particularly advantageous in the face of growing water scarcity [23].

In terms of fertilizer management, fertigation fulfils the requirement of using the right nutrient, applied at the right rate, right time, and in the right place toward improving system sustainability [22,24].

Common concepts adopted to evaluate the optimal amount of fertilizer are nitrogen balance and nitrogen use efficiency (NUE) $[8,25,26]$. Many studies have used different definitions of NUE to assess the efficiency of the nitrogen contained in livestock slurry and digestate $[27,28]$. In recent years, it has been observed that correct management of these fertilizers leads to higher nitrogen uptake efficiency [29-31]. It is now known that splitting the $\mathrm{N}$ application between pre-sowing and side dressing leads to better nitrogen use by plants [32]. In light of this, several techniques have been adopted for providing nitrogen during the growing season [33-35]. Particularly interesting are the techniques used to fertigate [36,37] with minerals [36,38,39] and slurries $[37,40]$, but there have, to date, been no reports of fertigation using digestate as a nitrogen source for plants.

The project "ARIMEDA-Ammonia emission reduction in Mediterranean agriculture with innovative slurry fertigation techniques" aims at demonstrating, to farmers and stakeholders related to agriculture, reductions in ammonia emissions achieved using innovative methods of manure application. The reduction of these emissions can be achieved through the implementation of advanced fertigation systems, using pig slurry in Spain and digestate in Italy, through low-pressure center pivots and drip irrigation systems. The ARIMEDA project pursues a more efficient use of natural resources, coming closer to a circular economy, reducing the dependency on imports and rare resources with increasing prices. This latter objective is also in the focus of the European Green Deal [41].

The aim of this study is to assess the performance of fertigation using liquid fraction of digestate on a maize crop with subsurface drip and low-pressure central pivot irrigation systems. These techniques were evaluated during two growing seasons at two commercial farms in which nutrient application was monitored to identify the potential and limitations of fertigation with digestate. The nitrogen use efficiency of the fertigated crops was compared to a crop where digestate was applied only before maize sowing.

\section{Materials and Methods}

This study took place at two farms in the Po valley (Lombardy, northern Italy) where maize was grown after winter cereals for the production of silage in two consecutive growing seasons (2018-2019). The use of fertigation techniques was compared with traditional irrigation as a reference using the same systems focusing on the agronomic performance and management using the liquid fraction of digestate after solid separation. 


\subsection{Study Area}

The area of the two farms is characterized by a humid subtropical climate [42]. The long-term average annual rainfall amounts to $860 \mathrm{~mm}$, with frequent air stagnation conditions.

The crop seasons, from sowing to harvest, were characterized by weather conditions typical of the area. At site 1, the rainfall was $224 \mathrm{~mm}$ in 2018 and $74 \mathrm{~mm}$ in 2019, the average temperatures were $24.6^{\circ} \mathrm{C}$ in 2018 and $25.1{ }^{\circ} \mathrm{C}$ in 2019 , and the average measured wind speed corresponded to light breeze during the two seasons $(2.0 \mathrm{~m} / \mathrm{s}$ in $2018,0.9 \mathrm{~m} / \mathrm{s}$ in 2019). The same trend was observed at site 2 , where the rainfall was $192 \mathrm{~mm}$ in 2018 and $95 \mathrm{~mm}$ and 2019, the average temperatures were $24.4^{\circ} \mathrm{C}$ in 2018 and $25.4^{\circ} \mathrm{C}$ in 2019 , and the average wind speed indicated light air and light breeze during the two seasons $(1.0 \mathrm{~m} / \mathrm{s}$ in $2018,1.4 \mathrm{~m} / \mathrm{s}$ in 2019$)$.

Weather data were recorded by a local weather station (Vintage Pro $2^{\mathrm{TM}}$, Davis Instruments Corporation, Hayward, CA, USA) installed near the fields at both sites.

The farm equipped with a central pivot (site 1$)$ is located in the province of Cremona $\left(45^{\circ} 4^{\prime} 9.00^{\prime \prime} \mathrm{N}\right.$, $10^{\circ} 7^{\prime} 39.14^{\prime \prime} \mathrm{E}$ ), while the second farm using drip irrigation (site 2) is located in the province of Mantua $\left(45^{\circ} 2^{\prime} 57.79^{\prime \prime} \mathrm{N}, 10^{\circ} 25^{\prime} 51.41^{\prime \prime} \mathrm{E}\right)$. Both farms manage a biogas plant fed with animal manure (pig slurry, cattle slurry, and poultry manure) and plant biomass (silage maize, wheat, barley, sorghum, sugar beet, and production residue).

Two fields were identified at each site: one for the fertigation treatments by pivot fertigation (P-F) and drip fertigation (D-F), and the other as a reference for traditional irrigation-the pivot reference (P-R) and drip reference (D-R). The whole fertigated area covered 10.6 ha for pivot and 19.1 ha for drip irrigation. The latter was divided into four fields numbered 1-4 (Figure 1). The area and main soil physical and chemical characteristics of the fields are summarized in Table 1.
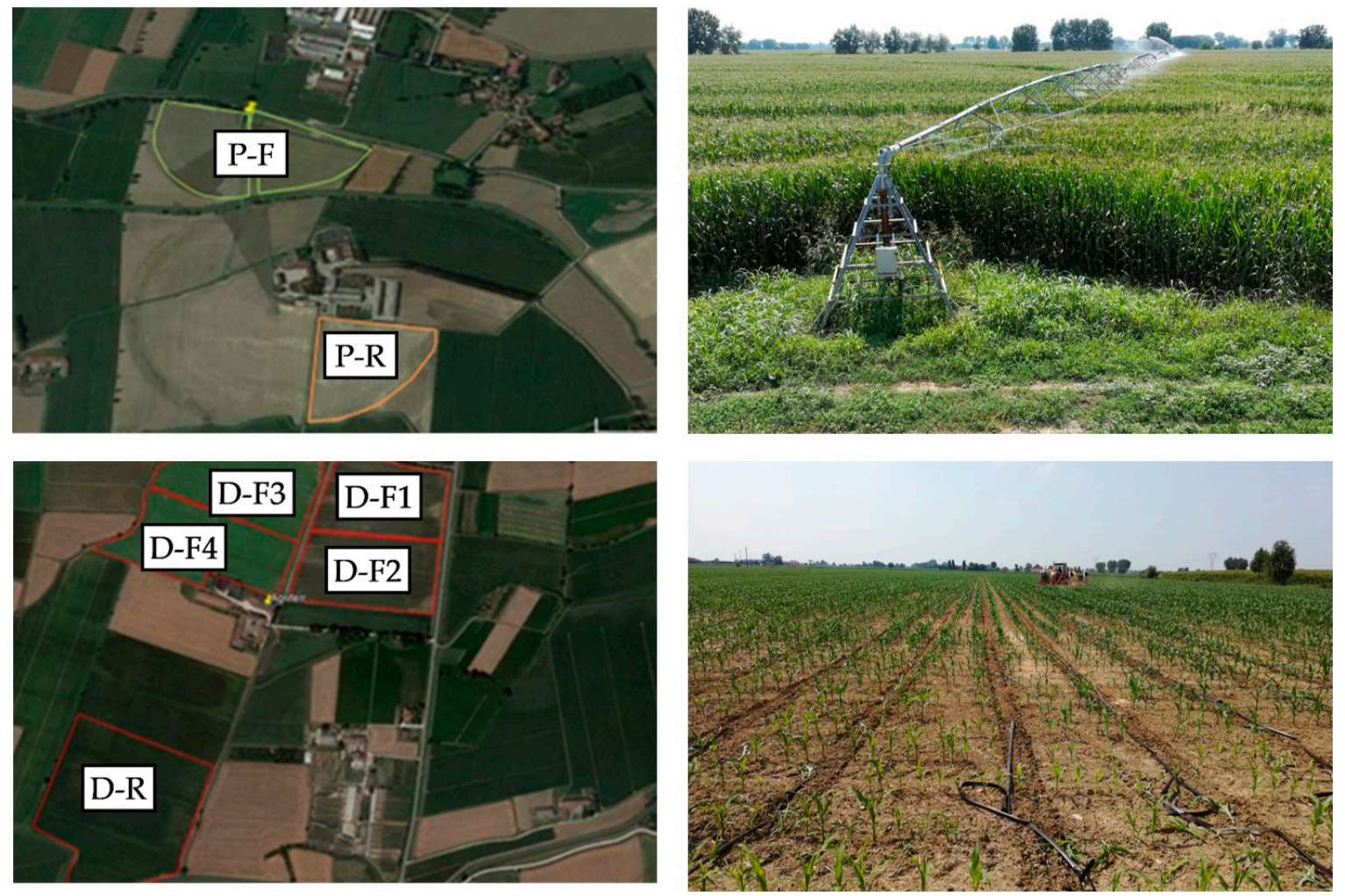

Figure 1. Study areas is the Po valley in northern Italy. Site 1 (pivot) is shown at the top and site 2 (drip irrigation) at the bottom; where P-R: Pivot Reference, P-F: Pivot-Fertigated, D-R: Drip Reference, D-F1, D-F2, D-F3, D-F4: Drip Fertigated fields. 
Table 1. Area, physical, and chemical characteristics of the soil for each field; where P-R:Pivot Reference, P-F: Pivot-Fertigated, D-R: Drip Reference, D-F1, D-F2, D-F3, D-F4: Drip Fertigated fields

\begin{tabular}{|c|c|c|c|c|c|c|c|c|c|}
\hline Site & Field & $\begin{array}{c}\text { Area } \\
\text { (ha) }\end{array}$ & $\begin{array}{l}\text { Sand } \\
(\%) *\end{array}$ & $\begin{array}{l}\text { Loam } \\
(\%) *\end{array}$ & $\begin{array}{l}\text { Clay } \\
(\%) *\end{array}$ & $\begin{array}{l}\text { Total N } \\
(\mathrm{g} / \mathrm{kg}) *\end{array}$ & $\begin{array}{l}\text { Organic } \\
\text { Carbon } \\
(\mathrm{g} / \mathrm{kg}) *\end{array}$ & $\begin{array}{c}\text { Organic } \\
\text { Matter } \\
(\%) *\end{array}$ & $\begin{array}{c}\mathrm{pH} \text { in } \\
\text { Water }\end{array}$ \\
\hline 1 & P-R & 7.0 & 23.3 & 71.8 & 5.0 & 3.3 & 23.1 & 4.0 & 7.5 \\
\hline 1 & P-F & 10.6 & 14.0 & 77.4 & 8.6 & 3.0 & 19.0 & 3.3 & 7.8 \\
\hline 2 & D-R & 7.0 & 11.3 & 59.2 & 29.5 & 2.5 & 13.7 & 2.4 & 7.0 \\
\hline 2 & D-F1 & 4.2 & 33.9 & 40.3 & 25.8 & 2.2 & 11.4 & 2.0 & 6.7 \\
\hline 2 & D-F2 & 4.5 & 22.0 & 51.7 & 26.3 & 2.4 & 14.5 & 2.5 & 6.6 \\
\hline 2 & D-F3 & 5.1 & 17.1 & 49.9 & 33.0 & 2.4 & 13.4 & 2.3 & 6.8 \\
\hline 2 & D-F4 & 5.3 & 13.0 & 53.9 & 33.2 & 2.5 & 12.1 & 2.1 & 6.9 \\
\hline
\end{tabular}

* Determined according to the standard methods described in the Italian Ministerial Decree of 13 September 1999.

The soils of the study sites can be classified as fulvic-eutric cambisols [43].

\subsection{Agronomic Management}

On the reference fields (P-R and D-R), digestate was applied as the base dressing on the wheat residues with a splash plate and incorporated after $24 \mathrm{~h}$. No other nitrogen fertilizer was applied to these fields during the cropping season.

In the fields with fertigation, digestate was applied both as the base dressing (raw digestate) and as side dressing with fertigation (digestate liquid fraction). The base dressing was applied via injection with an umbilical system. Fertigation with the digestate was performed with the pivot irrigation system in P-F and with the drip irrigation system in D-F1, D-F2, D-F3, and D-F4 between the 8th- and 12th-leaf stages of maize.

At site 1, the first season started on the 12th of June 2018. Raw digestate was spread in P-R $\left(85.2 \mathrm{~m}^{3} / \mathrm{ha}, 659 \mathrm{~kg} \mathrm{~N} / \mathrm{ha}\right)$ and P-F $\left(43.5 \mathrm{~m}^{3} / \mathrm{ha}, 337 \mathrm{~kg} \mathrm{~N} / \mathrm{ha}\right)$ with splash plate and umbilical systems, respectively (Table 2). Maize was sown between the 15th and 17th of June at a seeding density of $8 \mathrm{plant} / \mathrm{m}^{2}$ (Sagunto hybrid by FITO, FAO 700). Fertigation with the digestate liquid fraction was scheduled between the 20th of July and the 9th of August.

Table 2. Amount of digestate and doses of nitrogen applied in the base dressing at site 1 and site 2 .

\begin{tabular}{|c|c|c|c|c|c|c|c|}
\hline \multirow[b]{2}{*}{ Site } & \multirow[b]{2}{*}{ Field id } & \multicolumn{3}{|c|}{ Base Dressing in 2018} & \multicolumn{3}{|c|}{ Base Dressing in 2019} \\
\hline & & (m³ $/ \mathrm{ha})$ & (kg N/ha) & $\begin{array}{c}(\mathbf{k g} \\
\left.\mathrm{N}-\mathrm{NH}_{4} / \mathrm{ha}\right)\end{array}$ & $\left(\mathrm{m}^{3} / \mathrm{ha}\right)$ & (kg N/ha) & $\begin{array}{c}(\mathbf{k g} \\
\left.\mathrm{N}-\mathrm{NH}_{4} / \mathrm{ha}\right)\end{array}$ \\
\hline 1 & P-R & 85.2 & 659 & 378 & 73.6 & 461 & 297 \\
\hline 1 & P-F & 43.5 & 337 & 193 & 63.0 & 444 & 278 \\
\hline 2 & D-R & 112.5 & 464 & 344 & 229.9 & 942 & 680 \\
\hline 2 & D-F1 & 51.5 & 297 & 202 & 81.3 & 500 & 335 \\
\hline 2 & D-F2 & 47.3 & 273 & 185 & 81.3 & 500 & 335 \\
\hline 2 & D-F3 & 65.8 & 380 & 258 & 71.8 & 436 & 300 \\
\hline 2 & D-F4 & 63.8 & 368 & 250 & 71.8 & 429 & 297 \\
\hline
\end{tabular}

At site 2, the first season also started at the beginning of June 2018; $112.5 \mathrm{~m}^{3} / \mathrm{ha}(464 \mathrm{~kg} \mathrm{~N} / \mathrm{ha})$ of raw digestate was distributed in D-R by splash plate, whereas an average of $57.1 \mathrm{~m}^{3} / \mathrm{ha}(329.5 \mathrm{~kg} \mathrm{~N} / \mathrm{ha})$ was distributed by umbilical systems in fields D-F1, D-F2, D-F3, and D-F4 (Table 2).

Maize was sown on the 17th of June in D-R and on the 5th of July in D-F1, D-F2, D-F3, and D-F4 at a seeding density of 8 plant $/ \mathrm{m}^{2}$ (DKC6752 hybrid by Dekalb, FAO 600). The sowing in D-F was delayed because of rain events. Fertigation events were scheduled between the 31st of July and the 21st of August. 
The 2019 season started at site 1 on the 13th of June with the raw digestate applications in P-R $\left(73.6 \mathrm{~m}^{3} / \mathrm{ha}, 461 \mathrm{~kg} \mathrm{~N} / \mathrm{ha}\right)$ and P-F $\left(63 \mathrm{~m}^{3} / \mathrm{ha}, 444 \mathrm{~kg} \mathrm{~N} / \mathrm{ha}\right)$ with the same application techniques as used for the 2018 season. Maize was sown between the 18th and 21st of June at a seeding density of 7.5 plant $/ \mathrm{m}^{2}$ (KEBEOS hybrid by KWS, FAO 650). Fertigation events were scheduled between the 25th of July and the 12th of August.

At site 2, the second season started on the 8th of June with the raw digestate applications in D-R by the splash plate $\left(229.9 \mathrm{~m}^{3} / \mathrm{ha}, 942 \mathrm{~kg} \mathrm{~N} / \mathrm{ha}\right.$ ) and umbilical systems in D-F1, D-F2, D-F3, and D-F4 (on average $76.5 \mathrm{~m}^{3} / \mathrm{ha}, 466 \mathrm{~kg} \mathrm{~N} / \mathrm{ha}$ ); maize was sown between the 10th and 18th of June at a seeding density of 9.6 plant $/ \mathrm{m}^{2}$ (DKC6752 hybrid by Dekalb, FAO 600). Fertigation was scheduled between the 1st of August and the 12th of August.

The reference fields (P-R and D-R) at both sites received double the nitrogen amount of the fertigated fields (P-F, D-F1, D-F2, D-F3, D-F4), with the exception of site 1 in 2019, where P-R and P-F received the same amount of nitrogen (Table 2$)$.

The digestate was analyzed before each spreading to determine the content of the total Kjeldahl nitrogen (TKN), total ammonium nitrogen (TAN), total solids (TS), volatile solids (VS), suspended solids (SS), and pH using standard methods [44].

At both sites, tillage operations were carried out from the end of May to the beginning of June. In P-R and D-R, the base dressing application was followed by disk ploughing ( $20 \mathrm{~cm}$ depth) $24 \mathrm{~h}$ after application using a power harrow (15-20 cm depth) to incorporate the crop residues into the soil before sowing. In P-F, D-F1, D-F2, D-F3, and D-F4, minimum tillage was performed after the base dressing applications using a combined module of a disk harrow and disk plough at a depth of $20 \mathrm{~cm}$.

Pre-planting chemical weeding control was applied to all fields. Sowing was carried out using an 8-row pneumatic sowing machine with a double disk.

The phenological stages were recorded during the maize growing period. In 2018, the maize was harvested between the 28th and 29th of September at site 1 and between the 5th and 8th of October at site 2, and in 2019, between the 30th of September and the 1st of October at site 1 and between 14th and 15th of October at site 2 using a self-propelled forage harvester. The harvested biomass of each field was weighted (each trailer weight was recorded) to obtain the fresh weight yield. A subsample of the biomass was collected and then dried in an oven at $105^{\circ} \mathrm{C}$ for $48 \mathrm{~h}$ to obtain the dry matter and analyzed to obtain the TKN (Kjeldahl method).

\subsection{Irrigation Techniques}

The irrigation season at both sites and in both years started in mid-June and ended in August. At site 1, P-F, a central pivot system, was established on a semi-circular area $\left(180^{\circ}\right)$ of 10.6 ha, which was $240 \mathrm{~m}$ long with a terminal branch of $20 \mathrm{~m}$. In P-R, the pivot covered an area $\left(270^{\circ}\right)$ of $20.5 \mathrm{ha}$, $300 \mathrm{~m}$ long, with a terminal branch of $20 \mathrm{~m}$, but only 7 ha were monitored for this study.

In both pivots, the nozzles were positioned every $3 \mathrm{~m}$ at a $2.5 \mathrm{~m}$ height, and water was sprayed with a pressure of 4 bar. Water was pumped from the farm well via an electrical pump connected to the pivots with a mean flow rate of $90 \mathrm{~m}^{3} / \mathrm{h}$. The irrigation was generally performed once a week but was adopted according to precipitation events and crop demands; each irrigation event applied $15 \mathrm{~mm}$ of water.

At site 2, the five different fields under study (D-R, D-F1, D-F2, D-F3, and D-F4) were equipped with drip irrigation systems. In each field, new drip lines were installed every year, positioned every two rows of maize, i.e., every $1.4 \mathrm{~m}$, with drippers placed every $0.5 \mathrm{~m}$ under a nominal flow rate of $1.05 \mathrm{~L} / \mathrm{h}$ each. The water was pumped at 0.9 to 1.1 bar pressure in the fields by a mechanical pump with a power of $40 \mathrm{~kW}$ and an average flow rate of $62 \mathrm{~m}^{3} / \mathrm{h}$. Water was pumped from an irrigation channel and filtered by a hydraulic self-cleaning screen with 100 micron filters. The water amount applied in each event was, on average, $12 \mathrm{~mm}$. 


\subsection{Fertigation Requirements and Analysis}

To use the digestate as source for fertilization, different separations of solids are required to avoid clogging the drippers or nozzles. This separation was carried out with a screw press separator on both sites to remove solids larger than $1.2 \mathrm{~mm}$. Afterwards, the obtained liquid fraction was filtered with different equipment at each site according to the irrigation system's clogging risk (Figure 2).
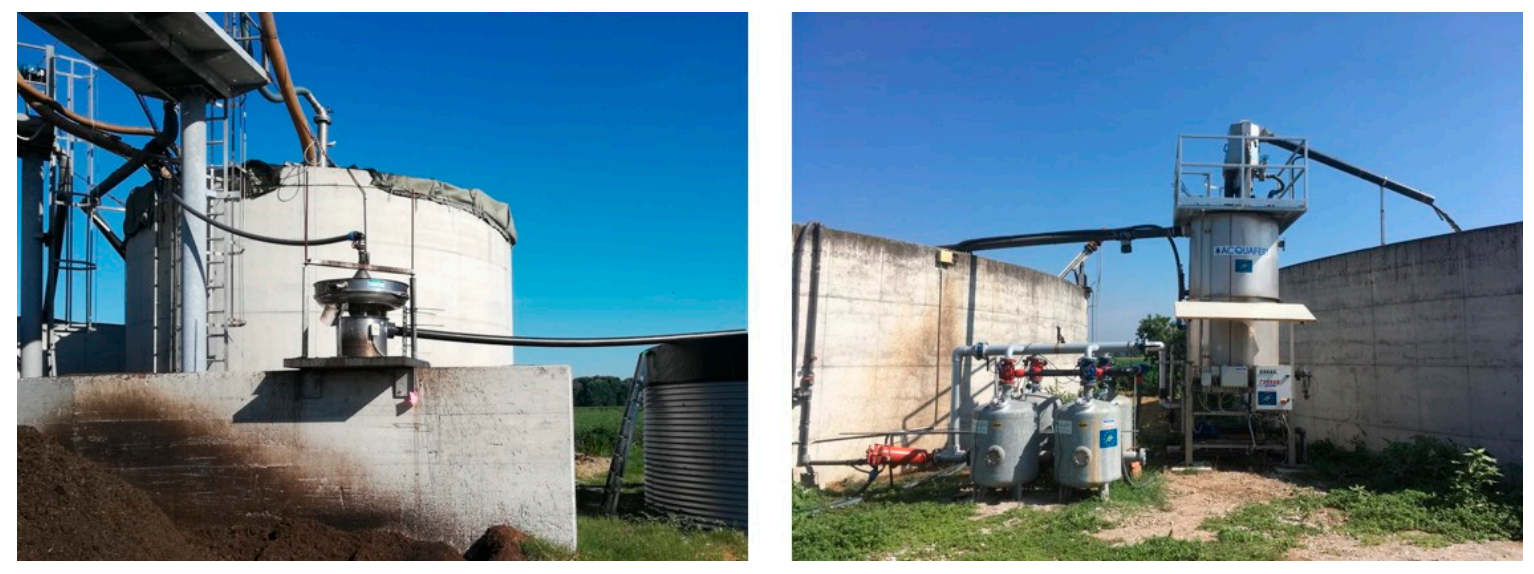

Figure 2. Prototypes separation filter adopted in site 1 for pivot (left) and in site 2 for drip irrigation (right).

In the central pivot irrigation system, a prototype vibrating screen (Acquafert, Cicognolo, Cremona, Italy) with a 200-micron net was used. To avoid clogging of the drippers at site 2 a microfilter (SEPCOM MFT Micro-filter, WAMGROUP Ponte Motta/Cavezzo, Modena, Italy) with a screen of 50 microns was used before injection in the line.

Filtered digestate (FD) was injected with a pump into the fields' irrigation systems. The number and duration of fertigation events were managed according to the performance of the injection systems. The liquid fraction of the digestate was sampled to analyze the nitrogen content in each fertigation event.

The irrigation water and FD injected volumes were measured in each fertigation event, and the water-digestate mix in the fertigation system was sampled and analyzed for TS to verify the dilution reached.

For each fertigation event, the systems were used with only water before and after digestate injection to clean the pipes and remove residue.

\subsection{Nitrogen Use Efficiency}

Nitrogen use efficiency (NUE; $\mathrm{kg} / \mathrm{kg}$ ) was calculated as the ratio of $\mathrm{N}$ uptake by the plant to the total $\mathrm{N}$ applied [45]:

$$
\text { NUE }=\frac{\mathrm{N} \text { uptake by the plant }}{\mathrm{N} \text { applied }} .
$$

The $\mathrm{N}$ uptake by the plant was determined using the aboveground biomass produced and the total $\mathrm{N}$ concentration of the harvested maize. The amount of $\mathrm{N}$ applied was calculated as the sum of $\mathrm{N}$ applied with the digestate before sowing and via fertigation for treatments P-F and D-F.

Descriptive statistical analysis has been carried out and standard deviation has been calculated on the data of the different fertigation events on the same field. 


\section{Results and Discussion}

\subsection{Agronomic Management}

Field Management

The obtained yields are reported in Table 3. The biomass harvested at site 1 in both seasons was certainly influenced by the different maize hybrids. In fact, while a hybrid with more rapid internode extension was chosen in 2018, the choice in 2019 was oriented towards a better performing hybrid in the production of spikes despite vegetal biomass production. This could explain the differences in yields: P-R reached more than 19 t/ha in 2018 but less than $15 \mathrm{t} /$ ha in 2019. Similar yields were obtained in P-F (20.5 t/ha and 15.2 t/ha in 2018 and 2019, respectively).

Table 3. Yields obtained during 2018 and 2019 in each field.

\begin{tabular}{cccccc}
\hline & \multicolumn{2}{c}{2018} & \multicolumn{2}{c}{2019} \\
\hline \multirow{2}{*}{ Site } & Field id & $\begin{array}{c}\text { Yield } \\
\text { (t/ha DM) }\end{array}$ & $\begin{array}{c}\text { Maize } \\
\text { Growing Days }\end{array}$ & $\begin{array}{c}\text { Yield } \\
\text { (t/ha DM) }\end{array}$ & $\begin{array}{c}\text { Maize } \\
\text { Growing Days }\end{array}$ \\
\hline 1 & P-R & 19.2 & 104 & 14.9 & 101 \\
1 & P-F & 20.5 & 105 & 15.2 & 102 \\
2 & D-R & 14.8 & 113 & 13.9 & 118 \\
2 & D-F1 & 14.7 & 93 & 16.5 & 125 \\
2 & D-F2 & 12.9 & 95 & 15.6 & 125 \\
2 & D-F3 & 10.5 & 92 & 13.4 & 124 \\
2 & D-F4 & 13.3 & 93 & 14.5 & 124 \\
\hline
\end{tabular}

At site 2, differences in the duration of the cultivation maize cycle for 2018 and 2019 significantly influenced the final yields, which were, on average, 12.9 t/ha in 2018 (with 93 days from sowing to harvest) and $15.0 \mathrm{t} /$ ha in 2019 (with a cycle of 125 days-32 days longer than the previous year). On the contrary, on D-R field with similar cycle durations for both years yields were around $14.0 \mathrm{t} /$ ha (Table 3).

Considering the amount of nitrogen applied as a base dressing, the possibility to visually determine variation in nitrogen uptake due to fertigation was very low. However, similar results were obtained by Yague and Quilez [45], who did not find significant maize yield differences between different fertilization strategies using pig slurry at rates from 30 to $120 \mathrm{~m}^{3} /$ ha as a base dressing complemented with mineral $\mathrm{N}$ as a side dressing.

Arbat el al. [46] also did not find significant differences in yields between treatments that received low rates of mineral $\mathrm{N}$ with fertigation but received $120 \mathrm{~kg}$ N/ha from pig slurry at pre-planting and treatments that received higher rates of mineral $\mathrm{N}$ as a side dressing.

\subsection{Fertigation Performance and Analysis}

At site 1, six fertigation application were performed in 2018 and four in 2019, while, in site 2, two fertigation application were achieved in both years.

The characteristics of the digestate sampled during each fertigation event are summarized in Table 4. After filtration, the concentrations of TAN and TKN in the digestate were still around or over $3 \mathrm{~g} / \mathrm{kg}$. Obviously after filtration, the concentrations remained comparable to that of the digestates commonly used in the area [47], with a TAN/TKN ratio between $60 \%$ and $74 \%$. Similarly, the TS\% and VS of TS fell into the ranges identified by Finzi et al. [47] for digestate. 
Table 4. Characteristics of the liquid fraction of the digestate after filtration at sites 1 and 2 during the 2018 and 2019 season (standard deviations in brackets).

\begin{tabular}{|c|c|c|c|c|c|c|c|c|}
\hline Site & Year & $\begin{array}{l}\text { TAN } \\
(\mathrm{g} / \mathrm{kg})\end{array}$ & $\begin{array}{l}\text { TKN } \\
(\mathrm{g} / \mathrm{kg})\end{array}$ & $\begin{array}{l}\text { Percentage } \\
\text { of TAN in } \\
\text { TKN }(\%)\end{array}$ & $\mathrm{pH}$ & $\begin{array}{c}\text { TS } \\
(\% \text { wb) }\end{array}$ & $\begin{array}{l}\text { Percentage of } \\
\text { VS in TS } \\
(\%)\end{array}$ & $\begin{array}{c}\text { SS } \\
\text { (\% wb) }\end{array}$ \\
\hline \multirow{2}{*}{1} & 2018 & $3.6( \pm 0.5)$ & $6.1( \pm 1.0)$ & $59.0( \pm 3.6)$ & $8.0( \pm 0.1)$ & $5.8( \pm 1.2)$ & $68.0 \%( \pm 1.0)$ & $2.3( \pm 0.7)$ \\
\hline & 2019 & $3.5( \pm 0.1)$ & $5.5( \pm 0.4)$ & $63.6( \pm 2.7)$ & $8.2( \pm 0.1)$ & $4.8( \pm 0.2)$ & $61.3 \%( \pm 0.4)$ & $2.5( \pm 0.3)$ \\
\hline \multirow[t]{2}{*}{2} & 2018 & $3.3( \pm 0.1)$ & $4.5( \pm 0.1)$ & $73.3( \pm 2.2)$ & $7.8( \pm 0.2)$ & $3.9( \pm 0.2)$ & $52.3 \%( \pm 0.8)$ & $2.1( \pm 0.1)$ \\
\hline & 2019 & $3.4( \pm 0.1)$ & $4.9( \pm 0.2)$ & $69.3( \pm 2.1)$ & $8.0( \pm 0.1)$ & $4.3( \pm 0.2)$ & $54.0 \%( \pm 0.9)$ & $2.3( \pm 0.2)$ \\
\hline
\end{tabular}

TAN: total ammonium nitrogen; TKN: total Kjeldahl nitrogen; TS: total solids; VS: volatile solids; SS: suspended solids; wb: wet basis.

According to the filtration strategies adopted, at site 1 the filtered digestate showed values comparable to those of the raw digestate, with a TS between $3.4 \%$ and $8.6 \%$, while at site 2 the TS of the filtered digestate varied between $2.5 \%$ and $4.7 \%$ [48].

At site 1, the TKN and TAN were relatively constant in both seasons, but TS was $4.8 \%$ in 2019 compared to $5.8 \%$ in 2018 , which could be attributable to the better operation of the filtration technologies adopted in 2019. This was also confirmed by the VS/TS ratios, which decreased from $68 \%$ in 2018 to $61.3 \%$ in 2019, while the SS increased from $2.3 \%$ in 2018 to $2.5 \%$ in 2019

At site 1, the amount of digestate applied during fertigation with pivot was 25.2 and $22.7 \mathrm{~m}^{3} / \mathrm{ha}$ in the 2018 and 2019 seasons, respectively, with a total nitrogen supply with fertigation of $152.6 \mathrm{~kg} \mathrm{~N} / \mathrm{ha}$ (2018) and $125.5 \mathrm{~kg} \mathrm{~N} / \mathrm{ha}$ (2019) (Table 5). This clearly demonstrates the feasibility of the technique under practical farming conditions.

Table 5. Characteristics of fertigation: digestate dose, total Kjeldahl nitrogen (TKN), and ammonium nitrogen (TAN) doses applied, and number of fertigation events at site 1 and site 2 .

\begin{tabular}{cccccccccc}
\hline & \multicolumn{3}{c}{ Fertigation 2018 } & \multicolumn{4}{c}{ Fertigation 2019 } \\
\hline Site & Field & $\begin{array}{c}\text { Dose } \\
\left(\mathbf{m}^{\mathbf{3}} \mathbf{/ h a}\right)\end{array}$ & $\begin{array}{c}\text { TKN } \\
\mathbf{( k g} / \mathbf{h a})\end{array}$ & $\begin{array}{c}\text { TAN } \\
\mathbf{( k g} / \mathbf{h a})\end{array}$ & $\begin{array}{c}\mathbf{n}^{\circ} \\
\text { Fertigation }\end{array}$ & $\begin{array}{c}\text { Dose } \\
\left(\mathbf{m}^{\mathbf{3}} / \mathbf{h a}\right)\end{array}$ & $\begin{array}{c}\text { TKN } \\
\mathbf{( k g} / \mathbf{h a})\end{array}$ & $\begin{array}{c}\text { TAN } \\
\mathbf{( k g} / \mathbf{h a})\end{array}$ & $\begin{array}{c}\mathbf{n}^{\circ} \\
\text { Fertigation }\end{array}$ \\
\hline 1 & P-F & 25.2 & 152.6 & 91.0 & 6 & 22.7 & 125.5 & 79.6 & 4 \\
2 & D-F1 & 13.9 & 61.8 & 46.2 & 2 & 12.6 & 59.3 & 43.1 & 2 \\
2 & D-F2 & 7.0 & 31.3 & 23.3 & 2 & 11.3 & 56.6 & 38.3 & 2 \\
2 & D-F3 & 8.8 & 39.3 & 28.7 & 2 & 7.2 & 36.2 & 25.5 & 2 \\
2 & D-F4 & 8.6 & 38.2 & 27.8 & 2 & 8.1 & 39.4 & 27.8 & 2 \\
\hline
\end{tabular}

With the drip fertigation system (site 2), the applied digestate varied from 7.0 to 13.9 in 2018 and 7.2 to 12.6 in 2019, respectively (Table 5). Also the total nitrogen supplied via fertigation showed a considerable variation (2018: 31.3-61.8 kg N/ha; 2019: 36.2-59.3 kg N/ha). The microfilter used for separation experienced some problems during the season and these problems influenced the nitrogen dose applied in each field. Without these technical problems, as in D-F1, it was possible to apply $61.8 \mathrm{~kg} \mathrm{~N} / \mathrm{ha}$ in the two fertigation events. On the other hand, when the microfilter system was blocked several times like in the 2018 in D-F2, only $31.3 \mathrm{~kg} \mathrm{~N} / \mathrm{ha}$ was applied.

The nitrogen applied for each event ranged from 15.7 to $31.4 \mathrm{~kg} / \mathrm{ha}$ (Figure 3). In fact, regardless of the adopted fertigation system, it was possible to distribute more than $30 \mathrm{~kg} \mathrm{~N} / \mathrm{ha}$ in one event $(30.9 \mathrm{~kg}$ $\mathrm{N} / \mathrm{ha}$ in D-F1 in 2018, $31.4 \mathrm{~kg} \mathrm{~N} / \mathrm{ha}$ in P-F in 2019). The high variations in the dose per event applied in 2018 at site 2 reflect the inconstant performance of the system (Figure 3). In 2019, the amount of nitrogen applied at each fertigation event was also more uniform at site 2 (Figure 3 ). In this season, the doses applied for each event ranged from 24.0 to $38.0 \mathrm{~kg} \mathrm{~N} / \mathrm{ha}$ at site 1 and from 13.3 to $31.1 \mathrm{~kg} \mathrm{~N} / \mathrm{ha}$ at site 2 . 


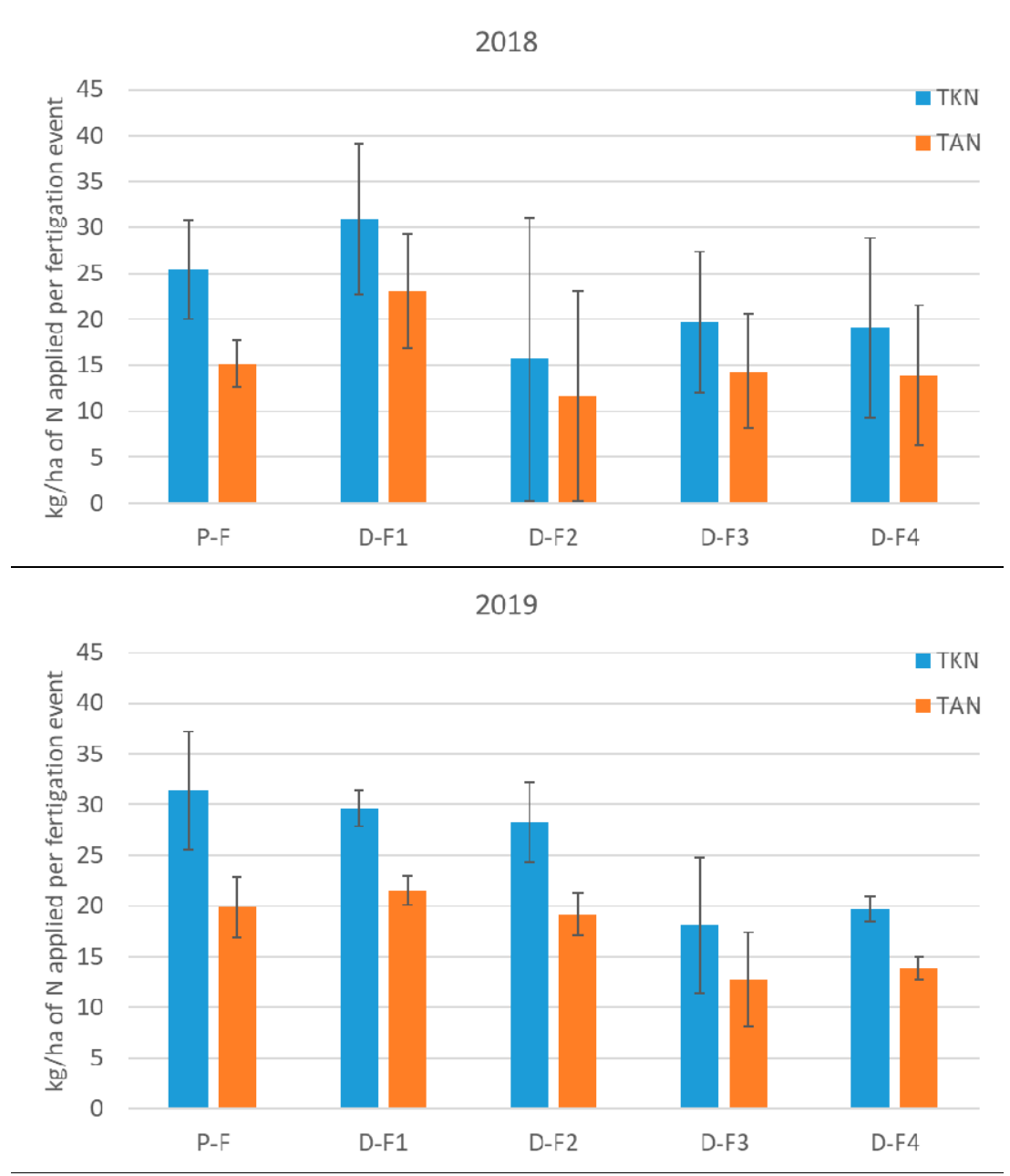

Figure 3. Average total Kjeldahl nitrogen (TKN) and ammonium nitrogen (TAN) applied in each fertigation event in 2018 (top) and 2019 (bottom) and their standard deviations (vertical bars).

The average application of digestate per event per hectare was $4.2 \mathrm{~m}^{3}$ and $5.7 \mathrm{~m}^{3}$ at site 1 in 2018 and 2019, respectively. At site 2, the average amount was $4.8 \mathrm{~m}^{3}$ in 2018 and $4.9 \mathrm{~m}^{3}$ in 2019 at the four fertigation fields.

For each fertigation event, the digestate and water amounts were also monitored to determine the dilution. The obtained results, which are reported in Table 6, show that the applied amount of digestate ranged from $3.2 \%$ to $4.3 \%$ in 2018 and from $3.4 \%$ to $4.0 \%$ in 2019 for both fertigation systems. In fact, these values are relatively low and could be increased up to $10 \%-20 \%$ without increasing the risk of clogging.

Table 6. Characteristics of fertigation events at sites 1 and 2: average digestate and water rate (standard deviation in brackets) for the years 2018 and 2019.

\begin{tabular}{|c|c|c|c|c|c|c|}
\hline & \multicolumn{3}{|c|}{ Site 1} & \multicolumn{3}{|c|}{ Site 2} \\
\hline & $\begin{array}{c}\text { Digestate } \\
\left(\mathrm{m}^{3} / \mathrm{ha}\right. \\
\text { Event) }\end{array}$ & $\begin{array}{l}\text { Water } \\
\left(\mathrm{m}^{3} / \mathrm{ha}\right. \\
\text { Event) }\end{array}$ & $\begin{array}{l}\text { Dilution } \\
\quad(\%)\end{array}$ & $\begin{array}{c}\text { Digestate } \\
\left(\mathrm{m}^{3} / \mathrm{ha}\right. \\
\text { Event) }\end{array}$ & $\begin{array}{l}\text { Water } \\
\left(\mathrm{m}^{3} / \mathrm{ha}\right. \\
\text { Event) }\end{array}$ & $\begin{array}{l}\text { Dilution } \\
\quad(\%)\end{array}$ \\
\hline Fertigation & 4.2 & 128.8 & $3.2 \%$ & 4.8 & 137.0 & $3.4 \%$ \\
\hline 2018 & $( \pm 0.68)$ & $( \pm 16.57)$ & $( \pm 0.43)$ & $( \pm 2.28)$ & $( \pm 61.40)$ & $( \pm 0.9)$ \\
\hline Fertigation & 5.7 & 126.5 & $4.3 \%$ & 4.9 & 117.0 & $4.0 \%$ \\
\hline 2019 & $( \pm 0.76)$ & $( \pm 12.32)$ & $( \pm 0.2)$ & $( \pm 1.36)$ & $( \pm 30.4)$ & $( \pm 0.6)$ \\
\hline
\end{tabular}


In the present study, the digestate dilutions in both the drip and pivot systems were lower than those proposed by Bortolini [37], who used 10\% for a traveler boom, and by Kranz et al. [40], who used $20 \%$ with a pivot.

The digestate to water ratio was limited by the equipment used. As can be seen in Table 7, the flow rate of the digestate distributed in 2018 was $3.0 \mathrm{~m}^{3} / \mathrm{h}$ at site 1 and, on average, $2.3 \mathrm{~m}^{3} / \mathrm{h}$ at site 2 , whereas in 2019 , it was $4.1 \mathrm{~m}^{3} / \mathrm{h}$ at site 1 and $2.6 \mathrm{~m}^{3} / \mathrm{h}$ as the mean of the four fields at site 2 .

Table 7. Amount of filtered liquid digestate applied per hour $\left(\mathrm{m}^{3} / \mathrm{h}\right)$ at sites 1 and 2 in 2018 and 2019 (standard deviation in brackets).

\begin{tabular}{cccc}
\hline & & Fertigation 2018 & Fertigation 2019 \\
\hline Site & Field & $\left.\mathbf{( \mathbf { m } ^ { 3 }} \mathbf{h}\right)$ & $\left.\mathbf{( \mathbf { m } ^ { 3 }} \mathbf{h}\right)$ \\
\hline 1 & P-F & $3.0( \pm 0.34)$ & $4.1( \pm 0.23)$ \\
2 & D-F1 & $2.3( \pm 0.04)$ & $2.5( \pm 0.36)$ \\
2 & D-F2 & $2.3( \pm 0.98)$ & $2.6( \pm 0.43)$ \\
2 & D-F3 & $2.2( \pm 0.98)$ & $2.4( \pm 0.66)$ \\
2 & D-F4 & $2.2( \pm 0.84)$ & $2.8( \pm 0.18)$ \\
\hline
\end{tabular}

Importantly, the filtering system used at both sites in this study were prototypes, thereby limiting the system's working capacity. However, there are no technical limitations in increasing the size and capacity of the equipment.

The amount of applied water and the number of fertigation events reported in the literature for maize are variable. For example, according to Yin et al. [27] and Sandhu et al. [36], the use of a drip irrigation system and six events with $10-36 \mathrm{~mm}$ per event is useful to fertigate an intensified maize crop system. Conversely, in field experiment conducted by Arbat et al. [46], the nitrogen demand of plants was satisfied using only three events per season.

Notably, drip irrigation requires more accurate filtration of the digestate to avoid clogging of the drippers and therefore higher requirements on the technical performance of the equipment have to be requested. Although only two fertigation events per season were performed during the field test, a better setup of the filtration system could easily allow a higher number of applications. Considering the number of irrigation events available for fertigation, the entire $\mathrm{N}$ requirements for maize (around $240 \mathrm{~kg} \mathrm{~N} / \mathrm{ha}$ ) could be supplied by injecting liquid digestate between the 4th leaf stage and flowering.

The use of pivot systems facilitates fertigation with digestate because the greater nozzle hole diameter $(>2 \mathrm{~mm}$ ) leading to lower requirements for solid separation.

For the pivot systems, the dose of applied digestate was around $24 \mathrm{~m}^{3} /$ ha over $4-6$ events. This amount of digestate can be increased, and a total nitrogen application rate of more than $200 \mathrm{~kg}$ $\mathrm{N} /$ ha could easily be achieved.

Therefore, fertigation might be a suitable technique for fertilizing maize during the growing season. It must be emphasized that these results were obtained with a very short growing season (93-125 days) due to double cropping. The quantity of digestate applied via fertigation could be increased for longer growing season typical for maize grown as a first crop.

Increasing the digestate to water ratio to $10 \%$ would increase the applied dose of nitrogen to around $75 \mathrm{~kg}$ of nitrogen per event. Thus, considering that the number of irrigation events during the season can be greater than 10 [49], the amount of nitrogen that can be applied to the crop can easily cover the full crop requirements.

\subsection{Nitrogen Use Efficiency}

For the ARIMEDA project, the common operations of farmers were observed and their approach to slurry application monitored. The total nitrogen supply was unequal between sites and within fields because the necessity of farm manure management did not reflect real crop requirements. Depending 
on the season and the adopted operations, the total nitrogen supply ranged from 461 to $942 \mathrm{~kg} \mathrm{~N} / \mathrm{ha}$ in the reference fields and from 304 to $559 \mathrm{~kg} \mathrm{~N} / \mathrm{ha}$ in the fertigated fields (Figure 4).

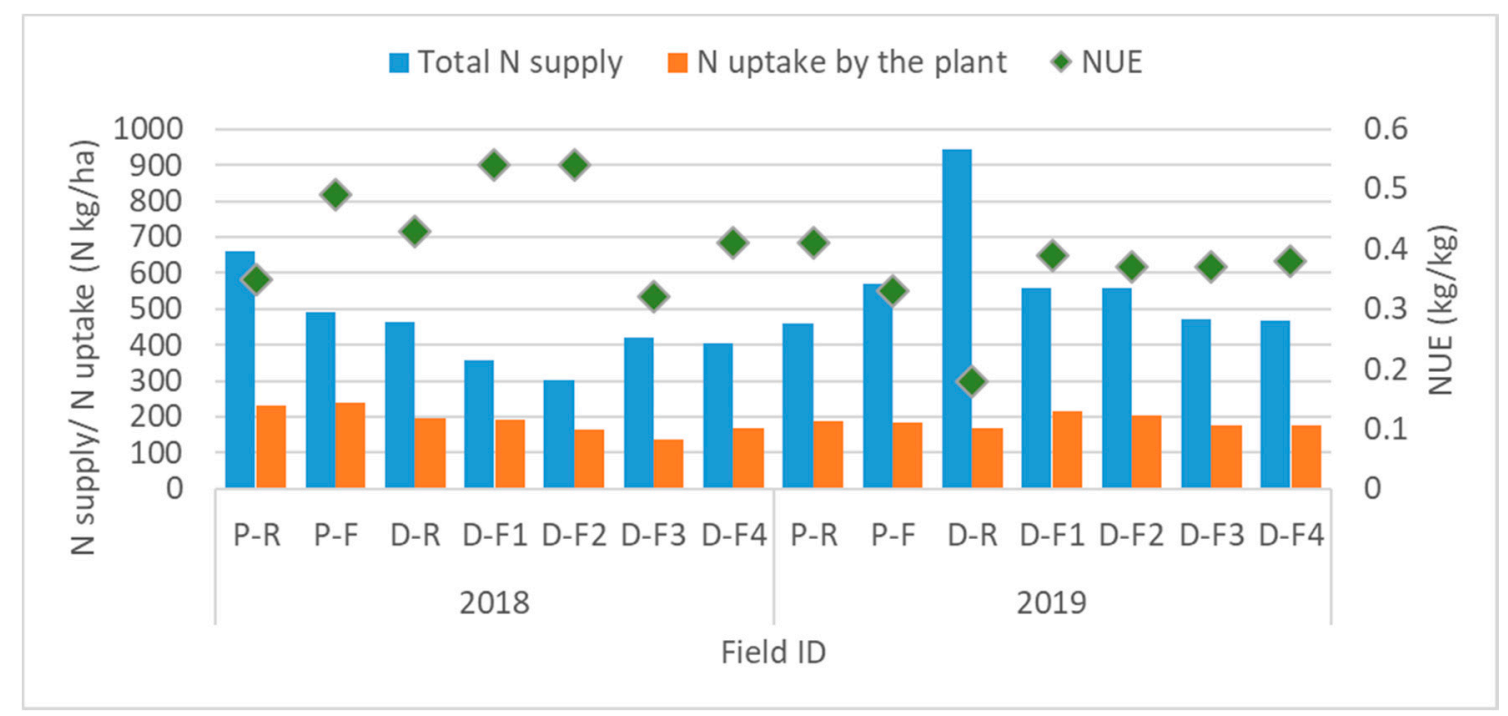

Figure 4. N supply, N uptake and Nitrogen use efficiency (NUE) at sites 1 and 2 during the 2018 and 2019 seasons.

$\mathrm{N}$ uptake by the plants at harvest (Figure 4) reached its maximum value at site 1 in P-F in 2018, with $238 \mathrm{~kg} \mathrm{~N} / \mathrm{ha}$, and the minimum (136 kg N/ha) at site 2 in D-F3 during the same year. This large discrepancy could be attributed to both the soil characteristics of each field and the different sowing dates of maize, which could have influenced the dynamics and timing of the removal of nutrients from the soil by the plants.

Although a statistical comparison of NUE is outside the aim of this work, some indications can be obtained from our results.

At site 1 in 2018, the NUE of P-F (0.49) was higher than that of P-R (0.35) due to the lower amount of nitrogen applied in P-F (Figure 4), which is associated with the positive effect of the fractioned application of N with fertigation. Conversely, in 2019, a higher NUE value was observed in P-R than in P-F. This result is certainly attributable to the higher total amount of nitrogen applied in P-F, which was $109 \mathrm{~kg} \mathrm{~N} /$ ha greater than that in P-R. At site 2 in 2018, the N uptake by the plants in D-R was higher than that in D-F1, D-F2, D-F3, and D-F4. This may be due to the longer crop period, as D-R was sown three weeks before D-F1, D-F2, D-F3, and D-F4.

Although a statistical analysis of the NUE data is not possible as the experiments were conducted under normal farm practice, in most cases the NUE values obtained in the fertigated fields are higher than the values obtained for the corresponding reference field

This was somewhat expected as the overall nitrogen application was, in all cases, well above the crop requirements. Nevertheless, an increase in the NUE is expected when the base dressing application of nitrogen is reduced, as occurred in some cases.

Likewise, Piccini et al. [50] and Demurtas et al. [38] obtained NUE values ranging between 0.49 and 0.50 in similar climatic and agronomic conditions with the application of cattle manure. In Zhang et al. [51], the nitrogen use efficiency reached 0.40 in drip fertigation trials, whereas in Sandhu et al. [36], the nitrogen use efficiency ranged from 0.26 to0.32 depending on the nitrogen dose (from 60 to $120 \mathrm{~kg} \mathrm{~N} / \mathrm{ha}$ ).

Furthermore, Berenguer et al. [52] previously concluded that optimal grain yields can be obtained by using a pig slurry as a base dressing without any side-dressed mineral N. On the other hand, Arbat et al. [46], Sandhu et al. [36], and Wu et al. [53] promote splitting the base dressing and fertigation events according to crop N uptake patterns to increase the NUE, while Yague and Quilez [45] 
recommended not applying doses higher than $130 \mathrm{~kg} \mathrm{~N} / \mathrm{ha}$ as a base dressing to reduce the risk of nitrate leaching due to late spring rains.

\section{Conclusions}

The results obtained using fertigation with digestate in pivot and drip irrigation systems confirmed the possibility to apply a significant dose of nitrogen during the cropping season with a potential increase of NUE and reduction in total nitrogen application.

It was demonstrated for both fertigation systems that, if properly managed, it is possible to apply quantities of nitrogen able to satisfy crop requirements.

Both the pivot and drip irrigation systems were suitable for fertigation, provided that the digestate was adequately filtrated according to the nozzle and dripper characteristics.

Further research on the use of fertigation should be carried out to confirm the obtained results and to evaluate side effects of this technique (e.g., $\mathrm{N}_{2} \mathrm{O}$ emission). Moreover, it would be helpful to assess the potential benefits for reducing ammonia emissions and improving the recycling of digestate as a valuable fertilizer in the circular economy.

Author Contributions: Conceptualization, G.P., D.Q., and V.G.; methodology, G.P. and E.H.; investigation, V.G. and A.F.; data curation V.G.; formal analysis, O.F. and E.R.; writing-original draft preparation, V.G.; writing-review and editing, V.G., G.P., D.Q., and E.H.; supervision, D.Q. and G.P. All authors have read and agreed to the published version of the manuscript.

Funding: This research was funded by LIFE ARIMEDA project (LIFE16 ENV/ES/000400).

Acknowledgments: We gratefully acknowledge the farmers for their hospitality of this project. We thank Acquafert srl as our project partners for their technical assistance and participation in the project activities. We thank Arianna Casarini, Pietro Piazzi, Nicola Salvi, Leonardo Scopelliti, and Pietro Tomasoni for their contributions to the data collection used in this investigation.

Conflicts of Interest: The authors declare no conflict of interest.

\section{References}

1. Vaneeckhaute, C.; Meers, E.; Michels, E.; Ghekiere, G.; Accoe, F.; Tack, F.M.G. Closing the nutrient cycle by using bio-digestion waste derivatives as synthetic fertilizer substitutes: A field experiment. Biomass Bioenergy 2013, 55, 175-189. [CrossRef]

2. Maucieri, C.; Barbera, A.C.; Borin, M. Effect of injection depth of digestate liquid fraction on soil carbon dioxide emission and maize biomass production. Ital. J. Agron. 2016, 11, 6-11. [CrossRef]

3. Jensen, L.S. Animal Manure Fertiliser Value, Crop Utilisation and Soil Quality Impacts. In Animal Manure Recycling; Sommer, S.G., Christensen, M.L., Schmidt, T., Jensen, L.S., Eds.; John Wiley \& Sons, Ltd.: Chichester, UK, 2013; pp. 295-328. ISBN 9781118676677.

4. Petersen, S.O.; Sommer, S.G.; Béline, F.; Burton, C.; Dach, J.; Dourmad, J.Y.; Leip, A.; Misselbrook, T.; Nicholson, F.; Poulsen, H.D.; et al. Recycling of livestock manure in a whole-farm perspective. Livest. Sci. 2007, 112, 180-191. [CrossRef]

5. Cavalli, D.; Bechini, L.; Di Matteo, A.; Corti, M.; Ceccon, P.; Marino Gallina, P. Nitrogen availability after repeated additions of raw and anaerobically digested $15 \mathrm{~N}$-labelled pig slurry. Eur. J. Soil Sci. 2018, 69, 1044-1055. [CrossRef]

6. Cavalli, D.; Cabassi, G.; Borrelli, L.; Geromel, G.; Bechini, L.; Degano, L.; Marino Gallina, P. Nitrogen fertilizer replacement value of undigested liquid cattle manure and digestates. Eur. J. Agron. 2016, 73, 34-41. [CrossRef]

7. UNECE United Nations Economic Commission for Europe Framework Code for Good Agricultural Practice for Reducing Ammonia Emissions. Available online: http://www.unece.org/environmental-policy/ (accessed on 29 April 2020).

8. Webb, J.; Sørensen, P.; Velthof, G.; Amon, B.; Pinto, M.; Rodhe, L.; Salomon, E.; Hutchings, N.; Burczyk, P.; Reid, J. Chapter Seven-An Assessment of the Variation of Manure Nitrogen Efficiency throughout Europe and an Appraisal of Means to Increase Manure-N Efficiency. Adv. Agron. 2013, 119, 371-442. [CrossRef] 
9. Alburquerque, J.A.; de la Fuente, C.; Ferrer-Costa, A.; Carrasco, L.; Cegarra, J.; Abad, M.; Bernal, M.P. Assessment of the fertiliser potential of digestates from farm and agroindustrial residues. Biomass Bioenergy 2012, 40, 181-189. [CrossRef]

10. Provenzano, M.R.; Iannuzzi, G.; Fabbri, C.; Senesi, N. Qualitative Characterization and Differentiation of Digestates from Different Biowastes Using FTIR and Fluorescence Spectroscopies. J. Environ. Prot. 2011, 2, 83-89. [CrossRef]

11. Provolo, G.; Mattachini, G.; Finzi, A.; Cattaneo, M.; Guido, V.; Riva, E. Global warming and acidification potential assessment of a collective manure management system for bioenergy production and nitrogen removal in Northern Italy. Sustainability 2018, 10, 3653. [CrossRef]

12. Provolo, G.; Perazzolo, F.; Mattachini, G.; Finzi, A.; Naldi, E.; Riva, E. Nitrogen removal from digested slurries using a simplified ammonia stripping technique. Waste Manag. 2017, 69, 154-161. [CrossRef]

13. Perazzolo, F.; Mattachini, G.; Tambone, F.; Calcante, A.; Provolo, G. Nutrient losses from cattle co-digestate slurry during storage. J. Agric. Eng. 2016, 47, 94-99. [CrossRef]

14. Nkoa, R. Agricultural benefits and environmental risks of soil fertilization with anaerobic digestates: A review. Agron. Sustain. Dev. 2014, 34, 473-492. [CrossRef]

15. Perazzolo, F.; Mattachini, G.; Tambone, F.; Misselbrook, T.; Provolo, G. Effect of mechanical separation on emissions during storage of two anaerobically codigested animal slurries. Agric. Ecosyst. Environ. 2015, 207, 1-9. [CrossRef]

16. Cattaneo, M.; Finzi, A.; Guido, V.; Riva, E.; Provolo, G. Effect of ammonia stripping and use of additives on separation of solids, phosphorus, copper and zinc from liquid fractions of animal slurries. Sci. Total Environ. 2019, 672. [CrossRef] [PubMed]

17. Plana, P.V.; Noche, B. A review of the current digestate distribution models: Storage and transport. Waste Manag. Environ. VIII 2016, 1, 345-357. [CrossRef]

18. Sarteel, M.; Tostivint, C.; Landowski, A.; Basset, C.; Muehmel, K.; Lockwood, S.; Ding, H.; Oudet, N.; Mudgal, S.; Cherrier, V.; et al. Resource Efficiency in Practice: Closing Mineral Cycles: Final Report; European Commission, Directorate-General for the Environment: Luxembourg, 2016; Volume KH-01-16-4.

19. Orzi, V.; Riva, C.; D'imporzano, S.B.; Tambone, F.; Adani, F. Anaerobic digestion coupled with digestate injection reduced odour emissions from soil during manure distribution. Sci. Total Environ. 2017, 621. [CrossRef]

20. Fangueiro, D.; Surgy, S.; Fraga, I.; Cabral, F.; Coutinho, J. Band application of treated cattle slurry as an alternative to slurry injection: Implications for gaseous emissions, soil quality, and plant growth. Agric. Ecosyst. Environ. 2015, 211, 102-111. [CrossRef]

21. Bacenetti, J.; Lovarelli, D.; Fiala, M. Mechanisation of organic fertiliser spreading, choice of fertiliser and crop residue management as solutions for maize environmental impact mitigation. Eur. J. Agron. 2016, 79, 107-118. [CrossRef]

22. Mikkelsen, R.; Hartz, T.K.; Rusan, M.J.M. Challenges of increasing water and nutrient efficiency in irrigated agriculture. In Managing Water and Fertilizer for Sustainable Agricultural Intensification, 1st ed.; Drechsel, P., Heffer, P., Magen, H., Mikkelsen, R., Wichelns, D., Eds.; International Fertilizer Industry Association (IFA), International Water Management Institute (IWMI), International Plant Nutrition Institute (IPNI) and International Potash Institute (IPI): Paris, France, 2015; Chapter 8; pp. 168-186. ISBN 979-10-92366-02-0.

23. Sharma, B.; Molden, D.; Cook, S. Water use efficiency in agriculture: Measurement, current situation and trends. In Managing Water and Fertilizer for Sustainable Agricultural Intensification; Pay, D., Heffer, P., Magen, H., Mikkelsen, R., Wichelns, D., Eds.; International Fertilizer Industry Association (IFA), International Water Management Institute (IWMI), International Plant Nutrition Institute (IPNI), and International Potash Institute (IPI): Paris, France, 2015; pp. 39-64. ISBN 979-10-92366-02-0.

24. Reetz, H.F., Jr.; Heffer, P.; Bruulsema, T.W. 4R nutrient stewardship: A global framework for sustainable fertilizer management. In Managing Water and Fertilizer for Sustainable Agricultural Intensification; Drechsel, P., Heffer, P., Magen, H., Mikkelsen, R., Wichelns, D., Eds.; International Fertilizer Industry Association (IFA), International Water Management Institute (IWMI), International Plant Nutrition Institute (IPNI), and International Potash Institute (IPI): Paris, France, 2015; Chapter 4; pp. 65-86. ISBN 979-10-92366-02-0.

25. Weih, M. A Calculation Tool for Analyzing Nitrogen Use Efficiency in Annual and Perennial Crops. Agronomy 2014, 4, 470-477. [CrossRef] 
26. Quemada, M.; Delgado, A.; Mateos, L.; Villalobos, F.J. Nitrogen Fertilization I: The Nitrogen Balance. In Principles of Agronomy for Sustainable Agriculture; Villalobos, F.F., Ed.; Springer: Cham, Switzerland, 2016; pp. 341-368.

27. Yin, G.; Wang, X.; Du, H.; Shen, S.; Liu, C.; Zhang, K.; Li, W. N2O and CO2 emissions, nitrogen use efficiency under biogas slurry irrigation: A field study of two consecutive wheat-maize rotation cycles in the North China Plain. Agric. Water Manag. 2019, 212, 232-240. [CrossRef]

28. Rasmussen, I.S.; Dresbøll, D.B.; Thorup-Kristensen, K. Winter wheat cultivars and nitrogen (N) fertilization-Effects on root growth, $\mathrm{N}$ uptake efficiency and $\mathrm{N}$ use efficiency. Eur. J. Agron. 2015, 68, 38-49. [CrossRef]

29. Zavattaro, L.; Costamagna, C.; Grignani, C.; Bechini, L.; Spiegel, A.; Lehtinen, T.; Guzmán, G.; Krüger, J.; D'Pose, T.; Pecio, A.; et al. Long-term effects of best management practices on crop yield and nitrogen surplus. Ital. J. Agron. 2015, 10, 47-50. [CrossRef]

30. Sandén, T.; Spiegel, H.; Stüger, H.-P.; Schlatter, N.; Haslmayr, H.-P.; Zavattaro, L.; Grignani, C.; Bechini, L.; D'Hose, T.; Molendijk, L.; et al. European long-term field experiments: Knowledge gained about alternative management practices. Soil Use Manag. 2018, 34, 167-176. [CrossRef]

31. Jarosch, K.; Richner, W.; Mayer, J. Nitrogen-use efficiency of biogas digestate. Rech. Agron. Suisse 2018, 3 , 76-81.

32. Quemada, M.; Delgado, A.; Mateos, L.; Villalobos, F.J. Nitrogen Fertilization II: Fertilizer Requirements. In Principles of Agronomy for Sustainable Agriculture; Villalobos, F.F., Ed.; Springer: Cham, Switzerland, 2016; pp. 369-380.

33. Oyebiyi, F.B.; Aula, L.; Omara, P.; Nambi, E.; Dhillon, J.S.; Raun, W.R. Maize (Zea mays L.) Grain Yield Response to Methods of Nitrogen Fertilization. Commun. Soil Sci. Plant Anal. 2019, 50, 2694-2700. [CrossRef]

34. Lazcano, C.; Tsang, A.; Doane, T.A.; Pettygrove, G.S.; Horwath, W.R.; Burger, M. Soil nitrous oxide emissions in forage systems fertilized with liquid dairy manure and inorganic fertilizers. Agric. Ecosyst. Environ. 2016, 225, 160-172. [CrossRef]

35. Panison, F.; Sangoi, L.; Durli, M.M.; Leolato, L.S.; Coelho, A.E.; Kuneski, H.F.; de Liz, V.O. Timing and splitting of nitrogen side-dress fertilization of early maize hybrids for high grain yield. Rev. Bras. Cienc. Solo 2019, 43. [CrossRef]

36. Sandhu, O.S.; Gupta, R.K.; Thind, H.S.; Jat, M.L.; Sidhu, H.S. Yadvinder-Singh Drip irrigation and nitrogen management for improving crop yields, nitrogen use efficiency and water productivity of maize-wheat system on permanent beds in north-west India. Agric. Water Manag. 2019, 219, 19-26. [CrossRef]

37. Bortolini, L. A low environmental impact system for fertirrigation of maize with cattle slurry. Contemp. Eng. Sci. 2016, 9, 201-213. [CrossRef]

38. Demurtas, C.E.; Seddaiu, G.; Ledda, L.; Cappai, C.; Doro, L.; Carletti, A.; Roggero, P.P. Replacing organic with mineral $\mathrm{N}$ fertilization does not reduce nitrate leaching in double crop forage systems under Mediterranean conditions. Agric. Ecosyst. Environ. 2016, 219, 83-92. [CrossRef]

39. Oker, T.E.; Kisekka, I.; Sheshukov, A.Y.; Aguilar, J.; Rogers, D.H. Evaluation of maize production under mobile drip irrigation. Agric. Water Manag. 2018, 210, 11-21. [CrossRef]

40. Kranz, L.W.; Koelsch, K.R.; Shapiro, A.C. Application of Liquid Animal Manures Using Center Pivot Irrigation Systems. Ext. Div. Circ. 2007, 1, 1-13. Available online: https:/extensionpubs.unl.edu/publication/ 9000016364607/application-of-liquid-animal-manures-using-center-pivot-irrigation-systems/ (accessed on 23 April 2020).

41. European Commission. The European Green Deal; European Commission: Brussels, Belgium, 2019; Volume 53, p. 24.

42. Rubel, F.; Brugger, K.; Haslinger, K.; Auer, I. The climate of the European Alps: Shift of very high resolution Köppen-Geiger climate zones 1800-2100. Meteorol. Z. 2017, 26, 115-125. [CrossRef]

43. IUSS Working Group WRB. World Reference Base for Soil Resources 2014, Update 2015; World Soil Resources Reports No. 106; International Soil Classification System for Naming Soils and Creating Legends for Soil Maps; FAO: Rome, Italy, 2015; p. 192.

44. APHA; AWWA; WEF. Standard Methods for Examination of Water and Wastewater, 22nd ed.; American Public Health Association: Washington, DC, USA, 2012; p. 1360. ISBN 978-087553-013-0. Available online: http://www.standardmethods.org/ (accessed on 29 July 2020). 
45. Yagüe, M.R.; Quílez, D. Response of Maize Yield, Nitrate Leaching, and Soil Nitrogen to Pig Slurry Combined with Mineral Nitrogen. J. Environ. Qual. 2010, 39, 686-696. [CrossRef] [PubMed]

46. Arbat, G.; Roselló, A.; Olivé, F.D.; Puig-Bargués, J.; Llinàs, E.G.; Duran-Ros, M.; Pujol, J.; de Cartagena, F.R. Soil water and nitrate distribution under drip irrigated maize receiving pig slurry. Agric. Water Manag. 2013, 120, 11-22. [CrossRef]

47. Finzi, A.; Oberti, R.; Negri, A.S.; Perazzolo, F.; Cocolo, G.; Tambone, F.; Cabassi, G.; Provolo, G. Effects of measurement technique and sample preparation on NIR spectroscopy analysis of livestock slurry and digestates. Biosyst. Eng. 2015, 134, 42-54. [CrossRef]

48. Zhang, X.; Xiao, G.; Li, H.; Wang, L.; Wu, S.; Wu, W.; Meng, F. Mitigation of greenhouse gas emissions through optimized irrigation and nitrogen fertilization in intensively managed wheat-maize production. Sci. Rep. 2020, 10, 1-10. [CrossRef] [PubMed]

49. Lovarelli, D.; Ingrao, C.; Fiala, M.; Bacenetti, J. Beyond the Water Footprint: A new framework proposal to assess freshwater environmental impact and consumption. J. Clean. Prod. 2018, 172, 4189-4199. [CrossRef]

50. Piccini, C.; Di Bene, C.; Farina, R.; Pennelli, B.; Napoli, R. Assessing nitrogen use efficiency and nitrogen loss in a forage-based system using a modeling approach. Agronomy 2016, 6, 23. [CrossRef]

51. Zhang, X.; Meng, F.; Li, H.; Wang, L.; Wu, S.; Xiao, G.; Wu, W. Optimized fertigation maintains high yield and mitigates $\mathrm{N} 2 \mathrm{O}$ and $\mathrm{NO}$ emissions in an intensified wheat-maize cropping system. Agric. Water Manag. 2019, 211, 26-36. [CrossRef]

52. Berenguer, P.; Santiveri, F.; Boixadera, J.; Lloveras, J. Fertilisation of irrigated maize with pig slurry combined with mineral nitrogen. Eur. J. Agron. 2008, 28, 635-645. [CrossRef]

53. Wu, D.; Xu, X.; Chen, Y.; Shao, H.; Sokolowski, E.; Mi, G. Effect of different drip fertigation methods on maize yield, nutrient and water productivity in two-soils in Northeast China. Agric. Water Manag. 2019, 213, 200-211. [CrossRef]

(C) 2020 by the authors. Licensee MDPI, Basel, Switzerland. This article is an open access article distributed under the terms and conditions of the Creative Commons Attribution (CC BY) license (http://creativecommons.org/licenses/by/4.0/). 